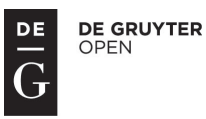

\title{
Disparities in Mortality Rates of Working-Age Population in EAstern, Central and WeStern Europe - A Comparative QuANTITATIVE ANALYSIS
}

\author{
Mária Lackó ${ }^{1}$
}

\begin{abstract}
Even two decades after the start of transition, mortality rates in Central and Eastern Europe are much higher than in Western Europe. This study presents and quantifies the impact on mortality of factors beyond the usual explanations. These factors are the advantageous and disadvantageous health effects of the geographical location of individual countries, as well as the economic structure, price structure and political priorities of the pre-transition systems in Central and Eastern Europe associated with anomic, self-destructive lifestyles. For adult males, mortality results show significant impact from level of development, health expenditure, latitude of countries, spirit consumption, education and air pollution. The impact of development, health expenditure, latitude, air pollution appear the same for both gender's mortality.
\end{abstract}

\section{Keywords}

Mortality Rate, Cross-country Comparison, Eastern, Central and Western Europe

\section{Introduction}

Even after two decades of political, economic and social convergence following the start of transition, mortality rates in the Eastern and Western parts of Europe show substantial differences. Much higher mortality in Central and Eastern Europe compared to Western Europe can only partly be attributed to differences in the level of development. This study aims to present and quantify the impact on mortality of further factors, such as the advantageous and disadvantageous health effects of the geographical location of individual countries, as well as the economic structure, price structure and political priorities of the pre-transition systems in Central and Eastern Europe associated with anomic, selfdestructive lifestyles. These factors influence the quality of human capital, the subjective

\footnotetext{
${ }^{1}$ Institute of Economics, Centre of Economic and Regional Studies, Hungarian Academy of Sciences,1112. Budapest, Budaörsi út 45, Hungary. E-mail: lackom@krtk.mta.hu.
} 
well-being of people, and macroeconomic productivity in the region not only in the short term, but in the long term as well.

In this study, equations explaining disparities in mortality rates are set up with the help of operationalizing the abovementioned variables. The sample of countries is made up of 46 Eastern, Central and Western European states; mortality data refers to the year 2011. Comparable multivariable regressional mortality equations (or more generally, health production functions) are usually calculated for OECD countries or groups of developing countries. The uniqueness of our analysis is partly related to our sample of countries comprising a large number of post-socialist states. Another novel feature of our approach is the inclusion of several explanatory variables that the literature in quantitative analysis of mortality rates has so far ignored. These variables are: 1. geographical location (latitude of countries) that operationalizes the often-discussed phenomenon of the Mediterranean paradox of mortality; 2. the most harmful form of air pollution (density of minor particulate matter in the air); 3. factors particularly prevalent in former socialist countries with longrun detrimental health effects (consumption of spirits, relative prices of alcohol beverages and tobacco products, hidden economy). Along with these variables, we also use traditional explanatory factors, such as level of development, health care expenditures and educational attainment.

In section II of this article, the values of mortality rates are presented across country groups and genders. In section III the possible explanatory factors of national mortality rates are selected and analyzed based on a broad literature of the subject and on rudimentary correlation rates. In section IV the selected explanatory variables are inserted into various multivariable regression equations (mortality equations); the results are summarized and conclusions are drawn in section $\mathrm{V}$.

\section{Mortality rates in Eastern, Central and Western Europe ${ }^{2}$}

This study looks at mortality rates of working-age populations of various countries in 2011 . The mortality rate of the working-age population is defined as the probability of dying between the ages of 15 and 60 for men and women, usually presented as the number of deaths out of 1,000 inhabitants. The countries included in our cross-sectional analysis are 46 European states and successor countries of the Soviet Union. ${ }^{3}$ The substantial variation in mortality rates across these countries is well illustrated by the fact that in 2011 the mean mortality rate among working-age men was 159 (out of 1,000), with the smallest value of 69 measured in Switzerland and the largest value of 351 in Russia. The corresponding indicators for women were substantially smaller (mean: 74, min: 38, Cyprus, max: 156,

\footnotetext{
${ }^{2}$ Definition of all the variables and indicators used in the paper as well as sources of data are listed in the Appendix.

${ }^{3}$ Old market economies: Austria, Belgium, Cyprus, Denmark, Finland, France, Germany, Greece, Ireland, Israel, Italy, Malta, the Netherlands, Norway, Portugal, Spain, Sweden, Switzerland, Turkey and Great Britain; CEE (Central and East European) countries: Albania, Bosnia and Herzegovina, Bulgaria, Croatia, the Czech Republic, Hungary, Macedonia, Poland, Romania, Serbia, Slovakia, Slovenia; PSS (Post-Soviet Union states): Estonia, Georgia, Kazakhstan, Kyrgyzstan, Latvia, Lithuania, Moldova, Russia, Tajikistan, Ukraine.
} 
Tajikistan). The reasons for this substantial variation are far from obvious. Our analysis is an attempt to give a satisfactory explanation.

The 46 countries of our broad sample vary in their geographical location, level of development, as well as economic system and culture (post-socialist versus long-established market economy) in 2011. The latter dimension gives rise to enormous differences in mortality: the mean mortality rates were 210 for men and 92 for women in the postsocialist countries, while the corresponding figures were 91 and 49 in long-established market economies. See also Figure 1, where the countries are further divided into three groups: long-established market economies, Central and East European countries (CEE) and post-Soviet Union states (PSS).

Figure 1: Mortality rates among working-age men and women by country groups, 2011

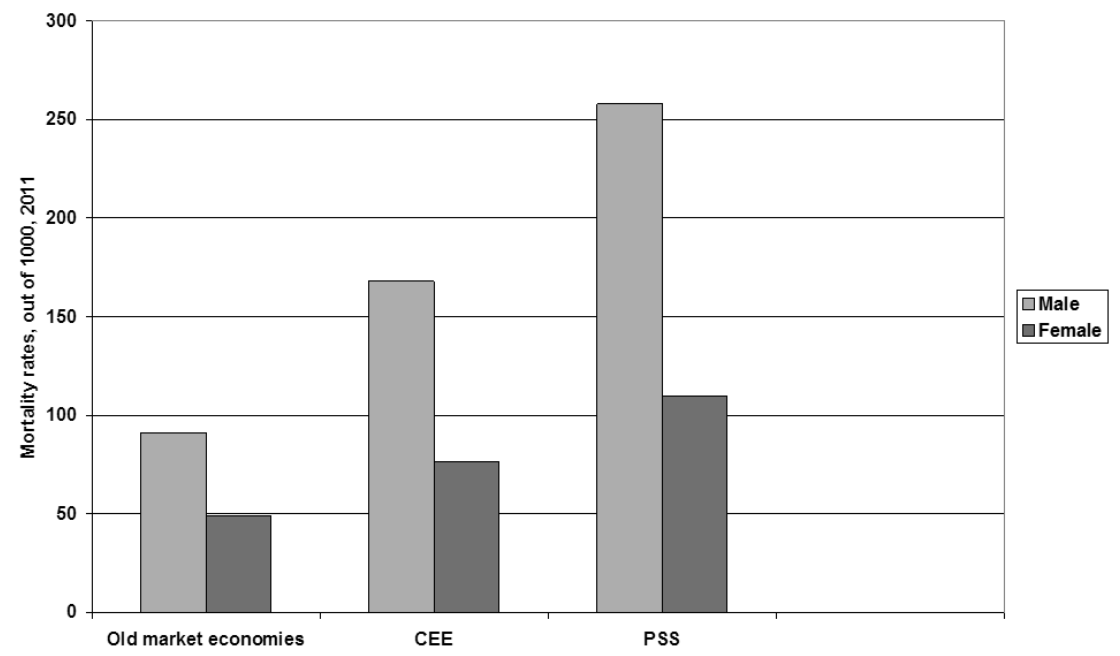

Our detailed analysis in this study is based on pairwise correlations and a regression analysis of mortality functions calculated from cross-country estimations for 2011. The explained variable is the mortality rate of the working-age population. The explanation focuses on three different groups of factors:

1. Factors related to location and economic system: geographical position of the country, air pollution, current level of economic development, the level of education.

2. Lifestyle factors: alcohol and tobacco consumption represented by their relative prices, consumption of spirits as a particularly damaging group of these consumption products, overwork in the hidden economy in the past and present, all of which are associated with the economic system.

3. Health care resources: health expenditure as a percentage of GDP. 


\section{The possible explanatory factors of mortality rates}

\section{The effects of level of development}

Based on the sample of 45 countries, Figure 2 displays the negative but, especially for the post-socialist countries, fairly weak correlation between the level of development of the selected economies and the mortality of working-age men in these countries. Some post-socialist countries, mostly those in the south, appear below the regression line, while the others from this group are well above the line.

Figure 2: Mortality rates of men and GDP per capita in 2011

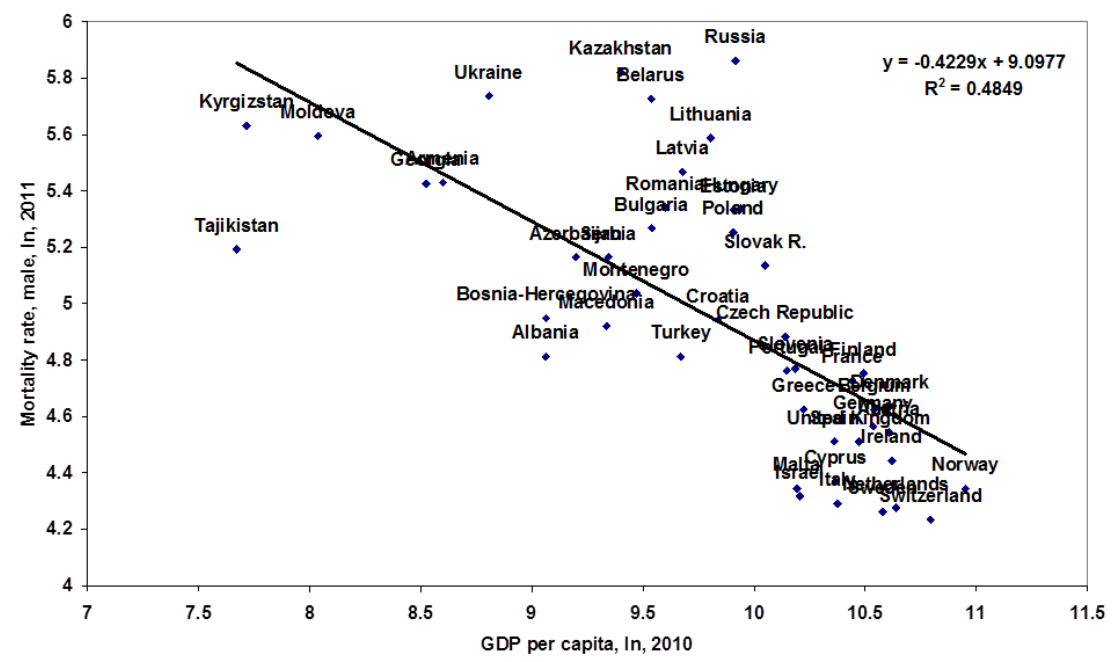

The weak correlations between level of development and mortality reflected by Figure 2 as well as the great divide between mortality rates according to different past political systems reflected by Figure 1 suggest that current mortality rates are affected not only by the current state of economic development, but also by a combination of various factors, some of them accumulated over a long period of time. In the subsequent sections below, we show that these factors are: the geographical location of the countries, past economic, social and political environment characterizing these countries and the lifestyle behaviors following from them, as well as the share of health care expenditures in GDP.

\section{The effects of geographical location}

The literature on European mortality clearly shows that there is a factor characteristic at one end of Mediterranean countries, where heart disease is a rare cause of death and at the other end of the north-eastern regions, where it is a frequent cause of death. Researchers are, however, divided on what mortality causes lie behind the effect of geographical position. 
This so-called Mediterranean paradox is investigated by Gjonça and Bobak (1997) through Albania, one of the poorest countries in Europe. The authors find that in Albania agestandardized heart disease mortality among 0-64 year-old men is half as high as in the United Kingdom, and as high as in Italy. The study concludes that the key to the Mediterranean paradox in Albania is eating habits: low consumption of total energy, meat and dairy products combined with high consumption of fruit, vegetables and carbohydrates. Grimes, Hindle and Dyer (1998) question Gjonça and Bobak's claims, arguing that geographical location predicts the frequency of coronary heart disease in itself. The authors explain the effect by the hours of sunshine determined by the Mediterranean latitude, which would have a direct beneficiary effect on human metabolism and protect the immune system thanks to increased vitamin D production. The real question is whether the effects of latitude are exerted directly by sunlight affecting human metabolism or indirectly through the dominance of agriculture and diet. It is not clear, the authors argue, whether olives (Albania's most important produce) are simply the embodiment of a climate or it is olive consumption per se that has a protective effect against coronary heart disease. Grimes, Hindle and Dyer prefer the former possibility, reasoning that the globalization of diet makes it unlikely that olive consumption could be the protector. They also note that, although researchers like to explain the development of heart disease, citing lifestyle factors and people's health-damaging behaviors, there are too many paradoxes by now. Besides the Albanian paradox, other studies discuss the French paradox, where harmful eating habits (with too much saturated fat) in the south of the country are coupled with low mortality, and the Italian paradox, where heart disease mortality remains low in spite of a rather high rate of smokers. Based on these arguments and on further results in the literature, we accept latitude as a likely explanatory variable in our investigation of mortality.

As a first approach of our examination, we carried out regression calculations on a sample of 46 countries: working-age mortality rate is used as the explained variable, and the level of economic development (GDP per capita), a dummy for the past political and socio-economic systems, as well as geographical location (latitude) are the explanatory variables. 
Table 1: Functions explaining variations in working-age mortality in 2011, 46 countries

\begin{tabular}{|c|c|c|c|c|c|c|c|c|c|c|c|c|}
\hline & [1] & & [2] & & [3] & & [4] & & [5] & & [6] & \\
\hline $\begin{array}{l}\text { Dependent variable } \\
\text { Mortality rate, } \ln , 2011\end{array}$ & $\begin{array}{l}\text { Male } \\
\text { coeff. }\end{array}$ & $\beta$ & $\begin{array}{l}\text { Female } \\
\text { coeff. }\end{array}$ & $\beta$ & $\begin{array}{l}\text { Male } \\
\text { coeff. }\end{array}$ & $\beta$ & $\begin{array}{l}\text { Female } \\
\text { coeff. }\end{array}$ & $\beta$ & $\begin{array}{l}\text { Male } \\
\text { coeff. }\end{array}$ & $\beta$ & $\begin{array}{l}\text { Female } \\
\text { coeff. }\end{array}$ & $\beta$ \\
\hline GDP per capita, $\ln , 2010$ & $\begin{array}{l}-0.51 * * \\
{[-8.21]}\end{array}$ & -0.84 & $\begin{array}{c}-0.44 * * \\
{[-12.83]}\end{array}$ & -0.93 & $\begin{array}{c}-0.23 * * \\
{[-3.48]}\end{array}$ & -0.38 & $\begin{array}{c}-0.32 * * \\
{[-5.99]}\end{array}$ & -0.67 & $\begin{array}{c}-0.35 * * \\
{[-5.12]} \\
\end{array}$ & -0.17 & $\begin{array}{l}-0.36^{* *} \\
{[-8.64]} \\
\end{array}$ & -0.75 \\
\hline Latitude & $\begin{array}{c}0.027 * * \\
{[4.16]}\end{array}$ & 0.4 & $\begin{array}{c}0.02 * * \\
{[4.81]}\end{array}$ & 0.37 & $\begin{array}{c}0.017 * * \\
{[3.20]}\end{array}$ & 0.24 & $\begin{array}{c}0.015 * * \\
{[4.06]}\end{array}$ & 0.29 & $\begin{array}{c}0.013 * * \\
{[2.47]}\end{array}$ & 0.19 & $\begin{array}{c}0.014 * * \\
{[3.37]}\end{array}$ & 0.26 \\
\hline Dummy for socialism & & & & & $\begin{array}{c}0.55^{* *} \\
{[4.99]} \\
\end{array}$ & 0.57 & $\begin{array}{c}0.24 * * \\
{[2.76]}\end{array}$ & 0.32 & & & & \\
\hline Dummy for CEE & & & & & & & & & $\begin{array}{l}0.32 * * \\
{[4.00]}\end{array}$ & 0.28 & $\begin{array}{c}0.09 \\
{[1.27]}\end{array}$ & 0.28 \\
\hline Dummy for PSS & & & & & & & & & $\begin{array}{l}0.40 * * \\
{[3.03]} \\
\end{array}$ & 0.37 & $\begin{array}{l}0.21^{*} \\
{[1.88]}\end{array}$ & 0.24 \\
\hline Constant & $\begin{array}{l}8.70 * * \\
{[12.9]}\end{array}$ & & $\begin{array}{l}7.64 * * \\
{[22.43]}\end{array}$ & & $\begin{array}{l}6.14 * * \\
{[9.36]}\end{array}$ & & $\begin{array}{l}6.52 * * \\
{[12.86]}\end{array}$ & & $\begin{array}{l}7.57 * * \\
{[11.00]}\end{array}$ & & $\begin{array}{l}7.03 * * \\
{[17.81]}\end{array}$ & \\
\hline R2 & 0.62 & & 0.74 & & 0.76 & & 0.76 & & 0.77 & & 0.79 & \\
\hline RMSE & 0.304 & & 0.196 & & 0.244 & & 0.18 & & 0.24 & & 0.18 & \\
\hline Number of obs. & 46 & & 46 & & 46 & & 46 & & 46 & & 46 & \\
\hline
\end{tabular}

$\beta$ : Standardized coefficients, t-statistic in parenthesis.

Level of significance: $* * 0.05, * 0.1$

Estimation method: OLS 
The results in Table 1 clearly show that geographical location affects male and female mortality in similar ways. We find that the mortality-reducing effect of level of development is more pronounced for women. The dummy variable for past political and socio-economic systems has a statistically significant detrimental effect on the mortality of both men and women, but this effect is far greater for male than for female mortality. The results of the models suggest that geographical location does not reflect lifestyle (diet) differences. If it did, there should be greater gender differences in the regression coefficients of the latitude variable (allegedly containing differences in diet), since women tend to have considerably more health-conscious eating habits than men. Importantly, the gender difference in the regression coefficients of the dummy variable of the past socialist regime, in contrast, is likely to follow from lifestyle differences: this variable has a far greater effect on men than on women (see Columns 3,4). A similar pattern can be observed for the dummy variables of CEE and PSS.

In the discussion below, we replace the dummy variables with "more visible", continuous variables that characterize the content of these dummy variables. In order to take into account lagged effect, we also look back in time and use average-over-time and sum-overtime type explanatory variables.

\section{Economic and social structure and working-age mortality}

The relationship between the quickly changing sectoral structure of the economy and working-age mortality was first noted by studies in the 1980s. These studies endeavored to analyze the unusual, rapidly increasing mortality trends observed in Eastern Europe in the second half of the 20th century (Cooper and Sempos, 1984, Giersdorf and Schuler, 1984, Józan, 1989). Since this phenomenon only appeared in state socialist countries, the authors termed it State Socialist Mortality Syndrome (Okolski, 1987, Forster and Józan, 1990, Hoehn and Pollard, 1991, Shkolnikov et al., 1998).

The first attempts to explain this syndrome focused on health care systems, population lifestyle as well as alcohol and tobacco consumption. Ivanov and Echenique (2000) provided evidence that the health care system alone could not be responsible for the development of the syndrome. Lifestyle appeared to be a more plausible explanation (Cockerham, 1997), but it was difficult to find out what could have changed people's lifestyle in such a way that mortality was increased as a result. Cornia and Paniccia (2000) observed that behaviors increasing the risk of mortality in Eastern European countries were manifestations of social chaos and stress. Cockerham et al. (2002) added that lifestyle and health may be related to passivity and other attitudes arising from socialist ideology.

\section{Sectoral structure in the past}

Carlson and Hoffmann (2011) and Mihályi (2010) observe a link between the characteristic structure of economic sectors in socialist economic systems and the increase in mortality in Eastern Europe: the forced growth in industry, and heavy industry in particular, and the suppression of the service sector created a norm-defying, anomic environment for men transferred from agriculture to industry, especially to heavy industry. Carlson and 
Hoffmann compared the employment structures in capitalist countries on the Northern and Southern peripheries of Europe to the employment structures in Eastern European countries in 1930, 1950 and then every five years from 1960 to 2005. While in 1930 and 1950 there was no major difference between European periphery capitalist countries and the East European countries in the ratio of industry to service sector workers, in the subsequently East European countries this ratio gradually increased from 1960 all the way to 1995, when it finally began to fall. Comparing these trends with working-age male mortality, the authors conclude that the increase in mortality rates follows excessive industrialization effected by state socialist policies by a lag of about ten years.

In Table 2 we show the direct pairwise correlations between working-age mortalities and the possible explanatory variables. In the case of four variables, we get very weak connections; however, in the following section we will see that these direct pairwise relationships are only part of the story: these variables will be significant and relevant explanatory variables in multivariable functions explaining the cross-country differences in mortality rates.

Calculations on our sample of countries presented in Table 2 reveal a strong negative correlation between the past production structure of an economy and current working-age mortality: as line 3 indicates, a higher past service sector share in GDP is associated with lower mortality. The service sector share in 1990 also shows a strong relationship with the GDP per capita in 2010 (see lines 1 and 3).

Table 2: Direct correlation coefficients between the mortality rates of males and females in 2011 and the explanatory variables

\begin{tabular}{|r|l|c|c|c|}
\hline & Variables & LNMORTM & LNMORTF & Number of obs. \\
\hline 1 & LNGDP10 & $-0.70^{* *}$ & $-0.80^{* *}$ & 40 \\
2 & LAT & 0.09 & 0.04 & 40 \\
3 & SERVICE90 & $-0.81^{* *}$ & $-0.81^{* *}$ & 40 \\
4 & HIDDEN & $0.77^{* *}$ & $0.77^{* *}$ & 40 \\
5 & RELPRICE & -0.05 & 0.08 & 40 \\
6 & ALCOHOL905 & 0.03 & -0.21 & 40 \\
7 & SPIRIT905 & $0.71^{* *}$ & $0.48^{* *}$ & 40 \\
8 & TOBACM09 & $0.65^{* *}$ & & 38 \\
9 & TOBACF09 & & $-0.47^{* *}$ & 38 \\
10 & SCHOOLYM9010 & -0.05 & & 40 \\
11 & SCHOOLYF9010 & & 0.02 & 40 \\
12 & PM259010sum & 0.08 & 0.09 & 40 \\
13 & HEGDP10 & $-0.53^{* *}$ & $-0.53^{* *}$ & 40 \\
\hline
\end{tabular}

** Significance level at 0.05

For explanations of variables, see Table A1 


\section{The relative size of the hidden economy}

Over-industrialization in socialist economies exerts its health-damaging effects both directly and indirectly. It does so directly by tipping the balance towards industries detrimental to human health (heavy industry, mining, etc.), and indirectly by giving rise to low-level and poor-quality services in the formal economy and to the health-damaging behaviors caused by the norm-defying (anomic) social environment. Under socialism and during the transition to market-economies, low-level and poor-quality services have at the same time generated an economy of informal services hidden from the taxation system. This hidden economy can also be detrimental to health both directly and indirectly, thus contributing to the high mortality observed in these countries (see Kopp et al. (2007), Mihályi, 2010). Bad-quality spirits circulating in the black market, for instance, have a direct negative effect on health, while indirect effects include the self-exploitative labor under bad and often dangerous working conditions with no health insurance in the hidden economy. The hidden economy also has its effect through health expenditures: less tax revenue allows smaller health care resources, possibly resulting in higher mortality.

Hidden economies are not restricted to socialist and post-socialist countries. They are also present in long-established capitalist countries, although different reasons and conditions give rise to them (e.g., high service prices or unemployment), and they are on a much smaller scale than in the socialist and post-socialist countries (see Table A in Appendix). We took country data calculated by Schneider (2012) for the size of the hidden economy (average for the period 1999-2007) and paired them with mortality rates for 2011. Line 4 in Table 2 shows that a prolonged higher share of the hidden economy in the past is associated with higher mortality among the countries in our sample.

\section{The price and consumption of alcohol and tobacco products}

An important basic relationship of micro-economics holds both in socialist and capitalist economies: alcohol and tobacco consumption is strongly related to the prices of consumer goods and, within that, to the prices of these products and the prices of other consumer products. There is mostly consensus in the literature that relatively low prices of harmful consumer goods (alcoholic beverages, tobacco, etc.) lead to extra consumption and thus to a decline in health.

Wagenaar, Salois and Komro (2009) carried out a meta-analysis of studies (1,003 publications were included) looking at the relationship between alcohol consumption on the one hand, and the price of alcohol and taxes on alcohol on the other. Every study finds a negative correlation between prices and consumption, although the strength of the correlation varies by type of alcohol and consumer group.

Whether influenced by low relative prices or by other factors, we find a great number of studies dealing directly with the consumption of alcohol and tobacco products and its consequences on public health. In their study, Hawkes and Buse (2013) analyzed gender differences in mortality and life expectancy worldwide in the past 40 years. Citing Lim et al.'s (2012) analysis of 67 health-detrimental risk factors, the authors find that the 10 most damaging factors are considerably more common among men than women. Of these 
ten factors, Hawkes and Buse (2013) find that, globally, alcohol consumption comes third following smoking and high blood pressure, but in Eastern Europe it is the first factor. The authors emphasize that, while there are physiological gender differences in the effects of alcohol consumption (in terms of alcohol absorption and metabolism), a larger part of the difference is rooted in "gender-determined" behaviors: men drink larger quantities of alcohol and more frequently.

Focusing on Eastern Europe, Treisman (2010) and Mihályi (2009) argue that the relatively low prices of alcoholic beverages and cigarettes make a substantial contribution to poor population health and the consequent increased mortality observed in this region through excessive drinking and smoking. Denisova (2010), however, reaches the opposite conclusion: she finds a weak positive correlation between the relative price of alcoholic beverages (vodka) and risk of mortality in Russia. The explanation for this counterintuitive pattern is that empirical experience shows that with a rise in the official price of vodka, there is an accompanying increase in the purchase of cheap vodka in the informal market, and this poor-quality beverage is harmful to health and leads to increased mortality.

Based on the evidence provided in the literature, our analysis should take a special look at the consumption of spirits, since it has been shown to be the alcohol product most detrimental to health, especially in the former socialist countries. Recently, a number of micro-studies have been carried out endeavoring to show the relationship between consumption of spirits and mortality, especially in the successor states of the Soviet Union. A recent paper by Zaridze et al. (2014) summarized the results of a longitudinal investigation of 151,000 adults with the aim of disclosing the effects of vodka consumption on mortality in Russia. The analysis of factors affecting vodka consumption gave interesting results: vodka consumption to some extent correlates with low educational attainment and manual labor, but shows the strongest correlation with smoking.

In our own investigation, we use internationally comparable prices for the product group of alcoholic beverages, tobacco and narcotics (the latter is not a focus of our investigation) for the year 2005 as well as internationally comparable prices for all consumption goods. The length of the lag between relative price indices (2005) and mortality data (2011) that we use is accidental: it was dictated by data availability. We assume that the relationship of prices of alcohol and tobacco products to prices of all consumption goods across countries has been stable for a long time, and that low and high relative prices had their effect on consumption and on health over many years.

In our cross-sectional correlation analysis presented in Table 2, we find that the direct correlation between alcohol consumption and male mortality is weak, while it is rather strong between spirit consumption and mortality (lines 6 and 7).

We also looked at the direct effects of smoking on mortality. The basic indicator in this case is the percentage of smokers in the male and female populations over the age of 15; this kind of data was available for 38 countries in our sample for 2009. The data in Table 2 reveals that male mortality increases with the share of smokers among men (line 8). Looking at women, the relationship appears to be negative (line 9). 


\section{Education}

The relationship between health and mortality on the one hand, and education on the other is widely studied in the literature. Every European country must face the fact that there are great inequalities in health and mortality among their population: those with lower educational attainment, those with lower employment status and those with lower incomes die younger and become ill with higher frequency.

In an overview of the literature, Lochner (2011) considers the various channels through which education leads to a healthier lifestyle and lower mortality. Some of these channels identified within societies may be considered to be working in our cross-country scheme as well. Education improves decision-making skills and may thus lead to better decisions on one's own health and more efficient utilization of health inputs (productive efficiency). Educated people also tend to be more efficient in collecting and interpreting information from physicians, from others or the Internet (allocative efficiency). Education helps to manage and alleviate stress. Educated people choose healthier and safer occupations and healthier lifestyles, are less likely to smoke or drink alcohol, and have healthier diets and get more physical exercise.

In our international comparative analysis, we calculate the coefficients for simple direct correlations between mortality rates in 2011 and the average years of total schooling among the $25+$ year-old population over the period 1990 to 2010 . Calculations reveal that there is a rather weak direct relationship between the education indicators and mortality rates on the total sample of countries (see lines 10 and 11 in Table 2). It is quite possible that this weakness is due to the composition of the investigated countries in terms of their economic and political system. In the sample of 40 countries, there are 20 developed market economies and 20 post-socialist countries. If we separate the sample by this dimension, we find that in the old capitalist countries the correlation coefficients have a much higher negative sign $(-0.68$ for male and -0.29 for female), so higher education levels are associated with much lower mortality rates, especially for men, than in the post-socialist countries (here the correlations are -0.31 for male and -0.43 for female. These latter results are not presented in Table 2.)

\section{Air pollution}

Epidemiological studies have shown an association between air pollution and a rise in the number of illnesses of the respiratory system, as well as mortality in the population due to cardiovascular diseases (Schwartz (1994), Bates (1992), Seaton, MacNee, Donaldson, Godden (1995), Kampa, Castanas (2008)). There are many categories of air pollutants, but only particulate matter (PM) is taken into account in this paper.

The explanation of acute and chronic effects of particulate air pollution is based on the chemical structure of this PM that changes blood coagulability and releases mediators able to provoke attacks of acute respiratory illness. In our sample, we have found no direct relationship between mortality rates in 2011 and the total amount of measured PM 2.5 micrograms $/ \mathrm{m}^{3}$ in the years from 1990 and 2010. (See line 12 in Table 2). 


\section{Health expenditure as a percentage of GDP}

Since 1960, in the developed economies in Europe, the health of the population has continuously improved at the macro level - usually measured in mortality or life expectancy. Health expenditure, i.e., total spending on health relative to GDP, has similarly been increasing. The cause and effect relationship between expenditure and outcome is, however, not straightforward, since health expenditure is only one of several quantitative and qualitative factors contributing to health outcomes.

A large share of studies analyzing health outcomes in terms of macro-level Health Production Functions mostly uses a sample of OECD countries and only occasionally a few developing market economies (see an overview by Nixon and Ulmann, 2006). The general conclusion of these studies (including that of Nixon and Ulmann, 2006) is that health expenditure and its in-kind, indirect indicators (e.g., the density of physicians) are statistically significant explanatory variables, and their expansion, ceteris paribus, increases life expectancy. The size of the effect is, however, typically found to be marginal, with the exception of infant mortality as an outcome.

Our own cross-country simple correlation analysis reveals a clear correlation between health expenditure and mortality: higher health expenditure is accompanied by a lower level of mortality (see line 13 in Table 2.).

Health expenditure can only insufficiently mirror the quality of health care in a country. The quality of health care is influenced, among others, by the institutional system, and the competence of the actors (doctors, assistants, patients), as well as the interconnection of the health care system with the research network (see Bernd et al., 2013). These factors do not necessarily show up in the quantitative indicator of the share of health expenditure in GDP. This share is, however, closely related to the level of development of a country, as well as to various demographic factors. Kornai and McHale (2000) and others (see a summary of the literature by Gray, 2005), for instance, showed that a higher share of elderly (65+) population in a country is associated, ceteris paribus, with a higher health expenditure per capita. Certainly, both of these variables, i.e. the level of development and the share of elderly population should be inserted as instruments into our multivariate mortality function, if we intend to investigate (as we do below) the effect of health expenditure on mortality. 


\section{A cross-sectional analysis with multiple regression functions}

In this section of the paper, the individual factors affecting mortality are combined in a regression model. The model includes the 40-45 countries for which data are available for each of the factors discussed in the previous sections.

The explained variable of the function is working-age male and female mortality in 2011 (in natural logarithm).

The following explanatory variables are included:

1. GDP per capita, in US dollars at PPP (in natural logarithm), in 2010.

2. Latitude of the countries.

3. Education: the average years of total schooling of $25+$ year-old people, average of values in 1990 and 2010 (in natural logarithm).

4. Per capita consumption of spirits in liters (in natural logarithm), in 1990-2005, average.

5. Share of the hidden economy in GDP, percent, 1999-2007 average.

6. Relative prices of alcohol and tobacco products and narcotics in 2005, (in natural logarithm).

7. Share of adult male and female smokers in 2009.

8. Air pollution: PM 2.5 micrograms $/ \mathrm{m}^{3}$ sum of annual values in the years 1990 , 1995, 2000, 2005 and 2010.

9. Health expenditure as a percentage of GDP in 2010.

10. Share of elderly (65+) population, percent, in 2010.

Before we show our regression functions, we have to refer back to Table 1, to our initial mortality functions. In Table 1 it was shown that mortality rates are strongly affected by the level of development, the latitude and a dummy variable of the past political and economic system of the investigated countries. One of the main results emerging from that analysis was that mortality in 2011 has still been strongly dependent on the economic and political system existing 20 years before that year. Now, in the course of our regression analysis, this dummy of the past economic and political system is replaced by a number of other explanatory variables characteristic of the socialist countries compared to developed capitalist countries. Past socialist countries had - beside a much lower level of GDP per capita - a lower share of health expenditure in GDP, a much higher share of the hidden economy, much higher consumption of spirits, and a higher share of smokers, especially for men. These countries had higher air pollution levels, too. The values of the chosen indicators of education in the past were slightly more favorable for the socialist counties than for the old market economies, so these variables may have an uncertain effect on mortality rates. (All these differences show up in Table A2 in Appendix.)

In Table 3 we show the combined effect of the abovementioned factors on male mortality rates with the help of cross-sectional regression functions.

The estimation method is the two stage least square method with Hubert-White sandwich estimator. The share of health expenditure in GDP is not exogenous, but is influenced 
by, among other factors, the share of elderly population (because older people use more health services than younger) and the share of the hidden economy in GDP (higher share of hidden economy decreases the tax revenues and social contributions, that indirectly decrease government health expenditure). These latter variables serve as instruments in the regression functions.

In Table 3 the regression results in columns 1 and 2 show the effects of GDP per capita, latitude, air pollution and health expenditure on male mortality according to data of 45 and 40 countries, respectively. The results are very similar in the two calculations: beside the negative coefficient of the development level and of the share of health expenditure, the proxy of the Mediterranean paradox (the latitude of a country) has a significant positive and strong effect on male mortality (see the standardized coefficients [beta] in column 1 and 2). In these functions, the proxy of air pollution significantly (but only at a $10 \%$ level) contributes to the mortality of males in the investigated sample. Column 3 shows regression results when further variables (education, spirit consumption, and the relative price of alcohol and tobacco products) are taken into account.

The weights of the negative effect of the development level, and health expenditure on male mortality are high with a similar magnitude (the standardized coefficients are -0.48 and -0.53 , respectively). These two factors are followed with a positive sign effect of the latitude and spirit-consumption with some lower weight ( 0.43 and 0.40 , respectively), and the rest of the explanatory variables show much lower weight (the coefficient of education is -0.19 , air pollution is 0.20 , and the relative price of alcohol and tobacco consumption is -0.16 ). It is interesting that the direct effect of the hidden economy is not significant on male mortality. Neither did we find a significant effect related to the prevalence of male tobacco consumption. The reason probably stems from the fact recorded in micro-level investigations that the connection between spirit consumption and the consumption of tobacco for males is strong: higher spirit consumption is associated with higher tobacco consumption. At the macro level, in our sample a similarly strong correlation is recorded between these explanatory variables (the coefficient of correlation is 0.54 ) in the case of males, but not in the case of females (correlation coefficient is 0.08 ). 
Table 3: Regression functions of working-age mortality in 2011, males

\begin{tabular}{|c|c|c|c|c|c|c|}
\hline $\begin{array}{l}\text { Dependent variable } \\
\text { Mortality rate, ln, male, } 2011\end{array}$ & $\begin{array}{l}{[1]} \\
\text { coeff. }\end{array}$ & $\beta$ & $\begin{array}{l}{[2]} \\
\text { coeff. }\end{array}$ & $\beta$ & $\begin{array}{l}{[3]} \\
\text { coeff. }\end{array}$ & $\beta$ \\
\hline GDP per capita, $\ln , 2010$ & $\begin{array}{l}-0.41 * * \\
{[-7.51]}\end{array}$ & -0.68 & $\begin{array}{l}-0.39 * * \\
{[-5.82]}\end{array}$ & -0.63 & $\begin{array}{l}-0.30 * * \\
{[-7.57]}\end{array}$ & -0.48 \\
\hline Latitude & $\begin{array}{c}0.037 * * \\
{[4.26]}\end{array}$ & 0.54 & $\begin{array}{c}0.036 * * \\
{[3.77]}\end{array}$ & 0.54 & $\begin{array}{c}0.029 * * \\
{[4.75]}\end{array}$ & 0.43 \\
\hline $\begin{array}{l}\text { The total price level of tobacco, } \\
\text { alcohol and narcotics products } \\
\text { relative to price level of all } \\
\text { consumption goods, } 2005\end{array}$ & & & & & $\begin{array}{l}-0.41 * * \\
{[-2.80]}\end{array}$ & -0.16 \\
\hline $\begin{array}{l}\text { Spirit consumption per capita in } \\
\text { the population aged } 15 \text { or over, } \\
1990-2005 \text {, average }\end{array}$ & & & & & $\begin{array}{c}0.30 * * \\
{[5.47]}\end{array}$ & 0.40 \\
\hline $\begin{array}{l}\text { Health expenditure as a percentage } \\
\text { of GDP, } 2010\end{array}$ & $\begin{array}{l}-0.08 * * \\
{[-2.54]}\end{array}$ & -0.34 & $\begin{array}{c}-0.090 * * \\
{[-2.43]}\end{array}$ & -0.38 & $\begin{array}{l}-0.12 * * \\
{[-6.53]}\end{array}$ & -0.53 \\
\hline $\begin{array}{l}\text { Average years of total schooling } \\
\text { in population aged } 25 \text { or over, } 1990 \\
\text { and } 2010 \text {, average }\end{array}$ & & & & & $\begin{array}{l}-0.80 * * \\
{[-2.53]}\end{array}$ & -0.19 \\
\hline $\begin{array}{l}\text { Air pollution: PM } 2.5 \\
\text { microgram/cubic meter, 1990-2009 } \\
\text { sum }\end{array}$ & $\begin{array}{l}0.41 * \\
{[1.91]}\end{array}$ & 0.24 & $\begin{array}{l}0.44 * \\
{[1.91]}\end{array}$ & 0.26 & $\begin{array}{l}0.32 * * \\
{[2.23]}\end{array}$ & 0.20 \\
\hline Constant & $\begin{array}{l}6.06 * * \\
{[4.13]}\end{array}$ & & $\begin{array}{l}5.82 * * \\
{[3.57]}\end{array}$ & & $\begin{array}{l}7.67 * * \\
{[7.91]}\end{array}$ & \\
\hline $\mathrm{R} 2$ & 0.72 & & 0.71 & & 0.87 & \\
\hline RMSE & 0.27 & & 0.28 & & 0.19 & \\
\hline Number of countries & 45 & & 40 & & 40 & \\
\hline Estimation method & INST & & INST & & INST & \\
\hline
\end{tabular}

It is important to mention that the effect of health expenditure is much higher in the estimation with instrumental variables than in the ordinary least square estimation (standardized coefficients are -0.53 versus -0.33 ).

The model in Table 3 also reflects that a higher health expenditure as a percentage of GDP is associated with a reduction in mortality for men. A 1 percentage point increase in the share of health spending is accompanied by a 12 percent decrease in mortality. To illustrate the weight of the individual factors, let us assume that in Hungary, health expenditure as a percentage of GDP were increased to the average level of old market economies (from 8.1 percent to 9.7 percent). In this case, Hungarian male mortality would fall from 208 to 171 per 1,000 men. This is a really strong effect. If, alternatively, per capita spirit consumption in Hungary moved to the level of the average of old market economies, from 4.39 liters to 1.8 liters, the model indicates a drop in Hungarian male mortality in 2011 from 208 to 159 per 1000 men $[(\ln (4.39)-\ln (1.8)) * 0.30]$. This latter effect of convergence in spirit 
consumption therefore surpasses even the effect of the hypothetical convergence in health expenditure. Female mortality functions are presented in Table 4.

By looking at the results, we can see that in our sample, spirit consumption, the relative price of tobacco and alcohol products, and education have no effect on the mortality of women. The lack of effects of the health-damaging factors on females can be explained by the generally lower incidence of alcohol and tobacco consumption by women than by men. The lack of significance of the level of education for women, and the weak effect for men, for that matter, is due to the strong correlation between the indicator of education and the development level (GDP per capita).

The coefficients of the other explanatory variables (GDP per capita, latitude, air pollution, and the share of health expenditure) are rather similar to those characterizing male mortality. The rank of the weights of the effects on the female mortality is similar to the case of males. In the explanation of mortality differences, in our sample the largest effect is shown by the variable GDP per capita (standardized coefficient is -0.66 ), followed by latitude and health expenditure (st. coefficient. are 0.48 and -0.44 respectively), while we find the lowest weight at the variable of air pollution (st. coefficient 0.21 ).

Table 4: Regression functions of working-age mortality in 2011, females

\begin{tabular}{|c|c|c|c|c|c|c|}
\hline $\begin{array}{l}\text { Dependent variable } \\
\text { Mortality rate, } \ln \text {, female, } 2011\end{array}$ & $\begin{array}{c}{[1]} \\
\text { coeff. }\end{array}$ & $\beta$ & $\begin{array}{c}{[2]} \\
\text { coeff. }\end{array}$ & $\beta$ & $\begin{array}{c}{[3]} \\
\text { coeff. }\end{array}$ & $\beta$ \\
\hline GDP per capita, ln, 2010 & $\begin{array}{r}-0.35 * * \\
{[-12.67]}\end{array}$ & -0.74 & $\begin{array}{r}-0.35 * * \\
{[-10.74]}\end{array}$ & -0.71 & $\begin{array}{c}-0.33^{* *} \\
{[-6.15]}\end{array}$ & -0.66 \\
\hline Latitude & $\begin{array}{c}0.027 * * \\
{[5.23]}\end{array}$ & 0.50 & $\begin{array}{c}0.027 * * \\
{[4.69]}\end{array}$ & 0.50 & $\begin{array}{c}0.026 * * \\
{[4.14]}\end{array}$ & 0.48 \\
\hline $\begin{array}{l}\text { Spirit consumption per capita in } \\
\text { the population aged } 15 \text { or over, } \\
1990-2005 \text {, average }\end{array}$ & & & & & $\begin{array}{c}0.08 \\
{[1.18]}\end{array}$ & 0.13 \\
\hline $\begin{array}{l}\text { Health expenditure as a percentage } \\
\text { of GDP, } 2010\end{array}$ & $\begin{array}{c}-0.071 * * \\
{[-3.38]}\end{array}$ & -0.39 & $\begin{array}{c}-0.077 * * \\
{[-3.02]}\end{array}$ & -0.41 & $\begin{array}{c}-0.083 * * \\
{[-3.64]}\end{array}$ & -0.44 \\
\hline $\begin{array}{l}\text { Average years of total schooling } \\
\text { in population aged } 25 \text { or over, } 1990 \\
\text { and } 2010 \text {, average }\end{array}$ & & & & & $\begin{array}{c}-0.22 \\
{[-1.00]}\end{array}$ & -0.08 \\
\hline $\begin{array}{l}\text { Air pollution: PM } 2.5 \\
\text { microgram/cubic meter, } \\
\text { 1990-2009 sum }\end{array}$ & $\begin{array}{l}0.28 * * \\
{[2.11]}\end{array}$ & 0.21 & $\begin{array}{l}0.30 * * \\
{[2.06]}\end{array}$ & 0.22 & $\begin{array}{l}0.29 * \\
{[1.85]}\end{array}$ & 0.21 \\
\hline Constant & $\begin{array}{l}5.76^{* *} \\
{[6.70]}\end{array}$ & & $\begin{array}{l}5.74 * * \\
{[5.72]}\end{array}$ & & $\begin{array}{l}6.09 * * \\
{[6.07]}\end{array}$ & \\
\hline R2 & 0.79 & & 0.79 & & 0.79 & \\
\hline RMSE & 0.18 & & 0.19 & & 0.20 & \\
\hline Number of countries & 45 & & 40 & & 40 & \\
\hline Estimation method & INST & & INST & & INST & \\
\hline
\end{tabular}




\section{Conclusion}

There is considerable variation in the mortality rate of the populations across the "old" and "new" EU member states, and non-member former Soviet Union countries. The explanation for these differences was investigated by scrutinizing three different groups of factors:

1. Factors related to location and the political and economic system: the geographical location of the country, current level of economic development and an indicator for air pollution.

2. Lifestyle factors: relative prices of alcohol and tobacco products, and their consumption of these products in the past, overwork in the hidden economy and education in the past and present.

3. Health care resources.

For the countries included in the analysis, the explanatory variables of the mortality function could explain 78-90 percent of the cross-country differences in mortality rates of the working-age population in 2011.

Our results give support to the theory of state socialist mortality syndrome. According to this theory, in communist countries, the forced growth of industry and the suppression of the service sector had created a norm-defying, anomic environment for a workingage population transferred in a short period of time from agriculture to industry. The social and behavioral consequences of this development accumulated over several decades and directly led to the increase in mortality. Over-industrialization in socialist economies exerted its health-damaging effects both directly (high share of industries detrimental to human health), and indirectly (low-level and poor-quality services in the formal economy, and health-damaging behaviors in the formal and informal economy).

Economic and lifestyle disadvantages turn out to be more harmful for men than women. The effects of the relative prices of alcohol and tobacco products, the consumption of spirits, and the education level are all significant explanatory factors for men, but are non-significant for women. The effects of the level of development, health expenditure, geographical location of the country, and the level of air pollution are, however, similar for the mortality of both genders.

One should not draw very bold policy conclusions from these results. After all, we have only one directly policy-related explanatory variable for mortality - the share of health expenditures in GDP - and a few other explanatory variables go back to the past, i.e., they exert their impact with a considerable time lag. We can safely establish, however, that government policies and regulations that support education, induce spending on health and roll back the consumption of spirits and cigarettes, as well as the reduction of particulate matter in the long run, are beneficial: they will contribute to the aim of reducing early mortality of the population in the less developed countries of Central and Eastern Europe and the successor states of the Soviet Union. 


\section{Acknowledgement}

This project has received funding from the Hungarian Scientific Research Fund (OTKA, 104400) and from European Union's Seventh Framework Programme (Growth - Innovation - Competitiveness: Fostering Cohesion in Central and Eastern Europe, 290657).

\section{References}

Barro, R., Lee, J. W. (2010). A New Data Set of Educational Attainment in the World, 1950-2010. Journal of Development Economics, 104, 184-198.

Bates, D. J. (1992). Health indices of the adverse effect of air pollution: the question of coherence. Environmental Research, 59, 336-349.

Bernd, R., Bayard, R., Richardson, E., Shishkin, S., Shkolnikov, V. M., Leon, D. A., Bobak, M., Karanikolos, M., McKee, M. (2013). Health and health systems in the Commonwealth of Independent States. The Lancet, 381(9872), 1145-1455.

Carlson, E., Hoffmann, R. (2011). The State Socialist Mortality Syndrome. Population Research and Policy Review, 2011 June, 30(3), 355-379.

Cockerham, W. C. (1997). The social determinants of the decline of life expectancy in Russia and Eastern Europe: a lifestyle explanation. Journal of Health and Social Behavior, 38(2), 117-130.

Cockerham, W. C., Snead, M. C., DeWaal, D. F. (2002). Health lifestyles in Russia and the socialist heritage. Journal of Health and Social Behavior, 43(1), 42-55.

Cooper, R., Sempos, C. (1984). Recent mortality patterns associated with economic development in Eastern Europe and the USSR. Journal of the National Medical Association, 76(2), 163-166.

Cornia, G., Paniccia, R. (2000). Mortality crisis of the early 1990s: a historical perspective. In: Cornia, A. G., Paniccia, R., editors. The mortality crisis in transitional economies, Oxford: Oxford University Press; 2000.

Denisova, I. (2010). Adult Mortality in Russia: A Microanalysis. Economics of Transition, 18(2), 333-363.

Forster, D. P., Józan, P. (1990). Health in Eastern Europe. The Lancet, 335(8687), 458-460.

Giersdorf, P., Schuler, H. (1984). Tendenzen der Mortalitaet mannlicher Personen im mittleren Alter. Zeitschrift für Artzliche Fortbildung, 78(3), 83-87.

Gjonça, A., Bobak, M. (1997). Albanian paradox, another case of the protective effect of Mediterranean lifestyle? The Lancet, 350(9094), 1815-1817.

Gray. (2005). Population Ageing and Health Care Expenditure. Ageing Horizons, 2, 15-20, Oxford Institute of Ageing, University of Oxford.

Grimes, D. S., Hindle, E., Dyer, T. (1998). Albanian paradox, another example of protective effect of Mediterranean lifestyle? The Lancet, 351(9105), 835-836.

Hawkes, S., Buse, K. (2013). Gender and global health: evidence, policy, and inconvenient truths. The Lancet, 381(9879), 1783-1787.

Hoehn, C., Pollard, J. (1991). Mortality in the two Germanys in 1986 and trends 1976-1986. European Journal of Population, 7, 1-28.

Ivanov, S., Echenique, V. (2000). Demographic situation and mortality trends in Russia, In: Kucera T. et al. (eds.). New Demographic Faces of Europe. Berlin: Springer Verlag. 287-304. 
Józan, P. (1989). Some features of mortality in postwar Hungary: the third epidemiological transition. Cahiers de Sociologie et de Demographie Medicales, 29(1), 21-42.

Kampa, M., Castanas, E. (2008). Human health effects of air pollution. Environmental Pollution, 151, 362-367.

Kopp, M., Skrabski, A., Szekely A., Stauder, A., Williams R. (2007). Chronic Stress and Social Changes, Socioeconomic Determination of Chronic Stress. Annals of New York Academy of Sciences, 1113, 325-338.

Kornai, J., McHale, J. (2000). Is Post-Communist Health Spending Unusual? Economics of Transition, 8(2), 369-399.

Lim, S. S., Vos, T., Flaxman, A., et al. (2012). A comparative risk assessment of burden of disease and injury attributable to 67 risk factors and risk factor clusters in 21 regions, 1990-2010: a systematic analysis for the Global Burden of Disease study 2010. The Lancet, 380, 2224-2260

Lochner, L. (2011). Non-production benefits of education: crime, health, and good citizenship. Working Paper, 16722, NBER, January.

Mihályi, P. (2010). Comparative study into causes of excess premature mortality in Hungary in comparison with selected CEE countries, Budapest, Europe Ltd.

Nixon, J., Ulmann, P. (2006). The relationship between health care expenditure and health outcome. Evidence and caveats for a causal link. European Journal of Health Economics, 7, 7-18.

Okolski, M. (1987). Male mortality trends in Eastern and Western Europe. Studia Demograficzne, 72(2), 3-28.

Schneider, F. (2012). The Shadow Economy and Work in the Shadow: What Do We (Not) Know? IZA Discussion Paper, 6423.

Schwartz, J. (1994). Air pollution and daily mortality: a review and meta-analysis. Environmental Research, 64, 36-52.

Seaton, A., MacNee, W., Donaldson, K., Godden, D. (1995). Particulate air pollution and acute health effects. The Lancet, 345(8943), 173-176.

Shkolnikov, V., Cornia, G., Leon, D., Mesle, F. (1998). Causes of the Russian mortality crisis: evidence and interpretations. World Development, 26(11), 1995-2011.

Treisman, D. (2010). Death and Prices: The Political Economy of Russia's Alcohol Crisis. Economics of Transition, 18(2), 281-331.

Wagenaar, A. C., Salois, M. J., Komro, K. A. (2009). Effects of Beverage Alcohol Price and Tax Levels on Drinking: A Systematic Review and Meta-analysis of 1003 Estimates from 112 Studies. Addiction, 104, 179-190.

WHS. (2013). World Health Statistics, III., 109-120.

World Bank. (2008). Global Purchasing Power Parities and Real Expenditures - 2005, International Comparison Program. The World Bank, Washington, D.C.

Zaridze, D, Lewington, S., Boroda, A., Scelo, G., Karpov, R., Lazarev, A., Konobeevskaya, I., Igitov, V., Terecova, T., Boffetta, P., Sherliker, P., Kong, X., Whitlock, G., Boreham, J., Brennan, P., Peto, R. (2014). Alcohol and mortality in Russia: prospective observational study 151,000 adults. The Lancet, 383(9927), 1465-1473. 
Table A1: Variables and sources of data

\begin{tabular}{|c|c|c|c|}
\hline Variables & Unit of measurement, year & The name of variable & Sources of data \\
\hline Adult male mortality* & per 1000 capita, 2011 & MORTM & WHS [2013] \\
\hline Adult female mortality* & per 1000 capita, 2011 & MORTF & WHS [2013] \\
\hline GDP per capita & 2010, PPP, dollar & GDP10 & WHO http://data.euro.who.int/hfadb \\
\hline Geographical location & latitude & LAT & www.mapsofworld.com/lat_long \\
\hline Share of services in GDP & percentage, 1990 & SERVICE90 & $\begin{array}{l}\text { World bank data, } \\
\text { data.worldbank.org/indicator }\end{array}$ \\
\hline The share of hidden economy in GDP & percentage, 1999-2007 average & HIDDEN & Schneider [2012] 61.-64. pp \\
\hline $\begin{array}{l}\text { The total price level of tobacco, } \\
\text { alcohol and narcotics products } \\
\text { relative to price level of all } \\
\text { consumption goods }\end{array}$ & 2005 & RELPRICE & World Bank [2008] \\
\hline $\begin{array}{l}\text { Alcohol consumption per capita in } \\
\text { the population aged } 15 \text { or over }\end{array}$ & liter, pure alcohol, 1990-2005 & ALCOHOL905 & http://data.euro.who.int./hfadb/tables \\
\hline $\begin{array}{l}\text { Spirit consumption per capita in } \\
\text { the population aged } 15 \text { or over }\end{array}$ & liter, pure alcohol, 1990-2005 & SPIRIT905 & http://data.euro.who.int./hfadb/tables \\
\hline $\begin{array}{l}\text { Prevalence of smoking any tobacco } \\
\text { products among adults aged } 15 \text { or over }\end{array}$ & $\begin{array}{l}2009 \\
\text { average of } 1990 \text { and } 2010\end{array}$ & $\begin{array}{l}\text { males: TOBACM09 } \\
\text { females: TOBACF09 }\end{array}$ & WHS [2013], 109.-120. pp \\
\hline $\begin{array}{l}\text { Education: Average years of total } \\
\text { schooling in population aged } 25 \text { or over }\end{array}$ & years & $\begin{array}{l}\text { males: SCHOOLYM9010 } \\
\text { females:SCHOOLYF9010 }\end{array}$ & Barro-Lee [2010], www.barrolee.com \\
\hline $\begin{array}{l}\text { Air pollution: PM } 2.5 \\
\text { microgram/cubic meter }\end{array}$ & $\begin{array}{l}\text { sum of } 1990,1995,2000,2005, \\
\text { and } 2010 \text { years }\end{array}$ & PM259010sum & $\begin{array}{l}\text { World Bank data } \\
\text { http://data.worldbank.org./indicator }\end{array}$ \\
\hline $\begin{array}{l}\text { Health expenditure as a percentage } \\
\text { of GDP }\end{array}$ & 2010, sum of public and private & HEGDP10 & $\begin{array}{l}\text { WHO, http://apps.who.int./ } \\
\text { who/data/node.main. } 75\end{array}$ \\
\hline The share of elderly $(65+)$ population & 2010 & OLD & http://data.euro.who.int./hfadb/tables \\
\hline
\end{tabular}

* Adult mortality is the probability of a 15-year-old dying before reaching the age of 60 ,

if subject to current age-specific mortality rates between those ages. 
Table A2: Statistics of variables

\begin{tabular}{|c|c|c|c|c|c|c|c|c|c|c|c|c|c|c|c|}
\hline $\begin{array}{l}\text { sample } \\
\text { variables }\end{array}$ & obs. & mean & $\begin{array}{l}\text { total } \\
\text { st. dev. }\end{array}$ & $\min$ & $\max$ & $\begin{array}{c}\text { post } \\
\text { obs }\end{array}$ & $\begin{array}{r}\text { socialist } \\
\text { mean }\end{array}$ & $\begin{array}{r}\text { countries } \\
\text { st. dev. }\end{array}$ & $\min$ & $\max$ & $\begin{array}{l}\text { old } \\
\text { obs }\end{array}$ & $\begin{array}{r}\text { market } \\
\text { mean }\end{array}$ & $\begin{array}{c}\text { ountries } \\
\text { st. dev. }\end{array}$ & $\min$ & $\max$ \\
\hline MORTM & 46 & 159 & 79 & 69 & 351 & 26 & 210 & 68 & 118 & 351 & 20 & 91 & 17 & 69 & 123 \\
\hline MORTF & 46 & 74 & 30 & 38 & 156 & 26 & 92 & 27 & 51 & 156 & 20 & 49 & 8 & 38 & 68 \\
\hline GDP10 & 46 & 23014 & 13493 & 2147 & 56976 & 26 & 13501 & 7106 & 2147 & 26509 & 20 & 35381 & 8941 & 15829 & 56976 \\
\hline SERVICE90 & 40 & 47 & 15 & 23 & 70 & 23 & 36.3 & 8.8 & 23 & 53.4 & 17 & 62 & 7.3 & 40.7 & 70.4 \\
\hline HEGDP10 & 46 & 8.3 & 2.1 & 4.4 & 12.1 & 26 & 7.3 & 1.8 & 4.4 & 11.7 & 20 & 9.7 & 1.7 & 5.6 & 12.1 \\
\hline HIDDEN & 45 & 29.2 & 12.7 & 8.5 & 65.8 & 25 & 36.8 & 11.2 & 18.1 & 65.8 & 20 & 19.7 & 6.4 & 8.5 & 31.3 \\
\hline LAT & 46 & 46.8 & 7.1 & 32.1 & 60.2 & 26 & 46.6 & 5.7 & 37.8 & 58.7 & 20 & 47.0 & 8.8 & 32.1 & 60.2 \\
\hline OLD & 46 & 14.3 & 4.1 & 3.0 & 21.0 & 26 & 13.0 & 4.2 & 3.0 & 18.0 & 20 & 15.9 & 3.5 & 7.0 & 21.0 \\
\hline RELPRICE & 46 & 1.1 & 0.2 & 0.7 & 1.5 & 26 & 1.1 & 0.2 & 0.8 & 1.4 & 20 & 1.1 & 0.3 & 0.7 & 1.5 \\
\hline SCHOOLYM9010 & 40 & 10.2 & 1.1 & 7.0 & 12.1 & 20 & 10.4 & 0.7 & 9.4 & 12.1 & 20 & 10.0 & 1.4 & 7.0 & 12.0 \\
\hline SCHOOLYF9010 & 40 & 9.7 & 1.3 & 5.1 & 11.6 & 20 & 10.0 & 0.8 & 8.8 & 11.6 & 20 & 9.4 & 1.6 & 5.1 & 11.5 \\
\hline SPIRIT905 & 46 & 3.0 & 1.9 & 0.6 & 8.9 & 26 & 3.8 & 2.0 & 0.6 & 9.0 & 20 & 1.8 & 0.7 & 0.6 & 3.3 \\
\hline TOBACM09 & 42 & 40.0 & 9.9 & 23.8 & 63.0 & 23 & 45.2 & 6.9 & 30.0 & 59.0 & 19 & 33.7 & 9.4 & 23.8 & 63.0 \\
\hline TOBACF09 & 42 & 22.1 & 10.0 & 2.0 & 45.0 & 23 & 20.0 & 11.2 & 2.0 & 41.0 & 19 & 24.6 & 7.8 & 13.0 & 45.0 \\
\hline PM259010sum & 46 & 91.5 & 21.5 & 40.7 & 134.3 & 26 & 95.8 & 15.5 & 53.8 & 118.7 & 20 & 85.7 & 26.7 & 40.7 & 134.3 \\
\hline
\end{tabular}

